\title{
Turning up the heat on COVID-19: heat as a therapeutic
}

\section{intervention [version 1; peer review: 1 approved, 1 approved}

\section{with reservations]}

\author{
Marc Cohen (10)
}

Extreme Wellness Institute, Melbourne, VIC, Australia

\begin{tabular}{l}
\hline V1 First published: 24 Apr 2020, 9:292 \\
https://doi.org/10.12688/f1000research.23299.1 \\
Latest published: 20 Jul 2020, 9:292 \\
https://doi.org/10.12688/f1000research.23299.2 \\
\hline
\end{tabular}

\section{Abstract}

Enveloped viruses such as SAR-CoV-2 are sensitive to temperature and are destroyed by temperatures tolerable to humans. All mammals use fever to deal with infections and heat has been used throughout human history in the form of hot springs, saunas, hammams, steamrooms, sweat-lodges, steam inhalations, hot mud and poultices to prevent and treat respiratory infections and enhance health and wellbeing. This paper reviews the evidence for using heat to treat and prevent viral infections and discusses potential cellular, physiological and psychological mechanisms of action. In the initial phase of infection, heat applied to the upper airways can support the immune system's first line of defence by supporting muco-ciliary clearance and inhibiting or deactivating virions in the place where they first lodge. This may be further enhanced by the inhalation of steam containing essential oils with anti-viral, mucolytic and anxiolytic properties. Heat applied to the whole body can further support the immune system's second line of defence by mimicking fever and activating innate and acquired immune defences and building physiological resilience. Heat-based treatments also offer psychological benefits by directing focus on positive action, enhancing relaxation and sleep, inducing 'forced-mindfulness', and invoking the power of positive thinking and remembered wellness. Heat is a cheap, convenient and widely accessible therapeutic modality and while no clinical protocols exist for using heat to treat COVID-19, protocols that draw from traditional practices and consider contraindications, adverse effects and infection control measures could be developed and implemented rapidly and inexpensively on a wide scale. While there are significant challenges in implementing heat-based therapies during the current pandemic, these therapies present an opportunity to integrate natural medicine, conventional medicine and traditional wellness practices, and support the wellbeing of both patients and medical staff, while building community resilience and reducing the likelihood and impact of future pandemics.

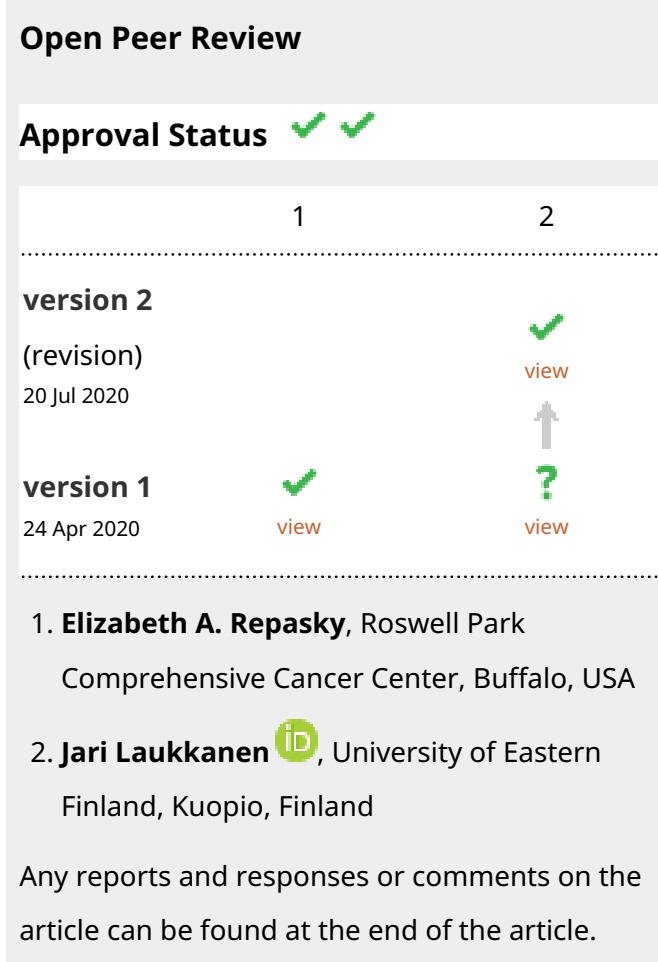




\section{Keywords}

Heat stress, hyperthermia, sauna, steam inhalation, balneotherapy,

COVID-19

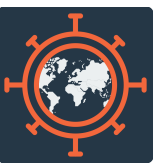

This article is included in the Emerging Diseases

and Outbreaks gateway.

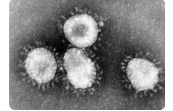

This article is included in the Coronavirus

collection.

Corresponding author: Marc Cohen (drmarc@extremewellness.co)

Author roles: Cohen M: Conceptualization, Resources, Writing - Original Draft Preparation, Writing - Review \& Editing

Competing interests: The author is a medical doctor who is a Board Member of the Global Wellness Summit and a shareholder in Maruia Hot Springs which is a boutique hot springs resort in the Southern Alps of New Zealand. He is also a Member of the Global Thermal Think Tank, Co-Founder of the Bathe the World Foundation and Founder of the Extreme Wellness Institute.

Grant information: The author(s) declared that no grants were involved in supporting this work.

Copyright: $\odot 2020$ Cohen M. This is an open access article distributed under the terms of the Creative Commons Attribution License, which permits unrestricted use, distribution, and reproduction in any medium, provided the original work is properly cited.

How to cite this article: Cohen M. Turning up the heat on COVID-19: heat as a therapeutic intervention [version 1; peer review: 1 approved, 1 approved with reservations] F1000Research 2020, 9:292 https://doi.org/10.12688/f1000research.23299.1

First published: 24 Apr 2020, 9:292 https://doi.org/10.12688/f1000research.23299.1 


\section{Heat in viruses and mammals}

Life exists within a narrowly defined temperature range, yet viruses, which are not technically alive, can remain biologically active in a wide range of environments. Enveloped viruses, such as rhinoviruses and coronaviruses, are most active in cool dry conditions, which are associated with increased occurrence of respiratory tract infections (Makinen et al., 2009), including infections with SARS-CoV (Chan et al., 2011) and SAR-CoV-2 (Sajadi et al., 2020; Wang et al., 2020). While enveloped viruses can remain active for long periods in cold conditions, their lipid envelopes are destroyed by temperatures tolerable to humans. The heat sensitivity of viruses is used routinely to deactivate viruses within vaccines, and temperatures of 55 to $65^{\circ} \mathrm{C}$ for 15 to 30 minutes are reported to deactivate a range of enveloped viruses, including coronaviruses (Darnell et al., 2004; Duan et al., 2003; Hu et al., 2011; Kampf et al., 2020; Lelie et al., 1987; WHO Report, 2003).

The first line of defence against respiratory viruses is the nasal cavity and sinuses, which maintains a protective mucosal barrier that allows viruses to be trapped, identified by the immune system and then swept away, as well as serving an important thermoregulatory role. The upper airways are constantly exchanging heat with inhaled air through convection, conduction and evaporation, which serves to cool inhaled air in summer and warm and humidify air in winter (Soni \& Nayak, 2019). The upper airways also filter inhaled air and trap foreign particles and pathogens in a layer of watery mucus that is continually moved by cilia towards the pharynx, where it is either swallowed or expelled by coughing, sneezing and nose blowing. A moist mobile mucosal barrier is vital in the defence against respiratory infections and this barrier is enhanced by warm humid conditions and impaired by cigarette smoke and particulate pollution (Fahy \& Dickey, 2010).

In winter when sunlight is restricted and the air is cold and dry, the nasal cavity becomes the coldest part of the body and if the airways dry out and the mucous becomes thicker and more difficult to clear, conditions become more favourable for viral penetration and replication. The ability of cool, dry conditions to enhance viral infection has been demonstrated in mice, with humidity of around $20 \%$ being shown to slow muco-ciliary clearance, impair innate antiviral defence, and reduce tissue repair function, leading to more rapid and severe illness compared with humidity of 50\% (Kudo et al., 2019).

If respiratory viruses get past the first line of defence, fever is produced as part of the acute phase response which forms the immune system's second line of defence. Fever is a cardinal response to infection that has been conserved throughout vertebrates for more than 600 million years. Ectotherms as diverse as reptiles, fish, and insects raise their core temperature during infection through behavioural regulation, and all mammals have evolved sophisticated mechanisms to create and disperse heat and manage the oxidative stress associated with operating at higher temperatures (Evans et al., 2015).

\section{Mechanisms of action}

The mechanisms by which heat overcomes viral infections depends on the setting, source, temperature, humidity, location and time course of applied heat. Whether internally generated or externally applied, heat has a profound influence on host defences and physiological resilience, as well as on viral load and virulence, and engages adaptive thermoregulatory mechanisms that can increase or decrease body temperature in order to restore homeostasis (Schieber \& Ayres, 2016).

Inhalation of hot air can support the immune system's first line of defence by directly inhibiting or deactivating virions in the upper airways where they first lodge and supporting mucociliary clearance, which can be further enhanced by inhalation of steam (Gujrathi et al., 2016). Heat applied to the whole body further supports the immune system's second line of defence by inducing heat-stress that mimics the effects of fever (Schieber \& Ayres, 2016). Fever has multiple actions when dealing with infections that includ direct inhibition of pathogens, stimulation of both the innate and adaptive arms of the immune system and activation of regulatory processes that serve to dampen inflammatory responses and avoid excessive tissue damage during the return to thermal homeostasis (Evans et al., 2015).

Febrile temperatures activate multiple cellular responses that include complex reciprocal regulation between immune system activation, inflammation and the heat shock response pathway (Singh \& Hasday, 2013). While the mechanisms by which heat-stress modulates immune function are not fully understood, higher temperatures have been shown to activate immune cells by making their cell membranes more fluid, which increases cell differentiation and activation by viral antigens and enables a faster and more effective response to viral threats (Mace et al., 2011). Acute heat stress has also been shown to increase the TNF-alpha response of monocytes (Zellner et al., 2002), enhance interleukin-2 induced activity of Natural Killer (NK) cells (Kappel et al., 1991), and cause a 10-fold increase in interferon- $\gamma$ production by T-lymphocytes (Downing et al., 1988). Regular heat-stress has also been shown to reduce adrenaline and cortisol, increase the cytotoxicity of NK cells, and enhance the proliferative response of B cells (Tomiyama et al., 2015). Heat-stress also stimulates the release of Heat Shock Proteins (HSPs), (Iguchi et al., 2012), which play an important role in antigen presentation and crosspresentation, activation of macrophages and lymphocytes, and activation and maturation of dendritic cells (Tsan \& Gao, 2009) as well as serving a chaperone function and protecting immune cells and proteins from heat-induced damage (Singh \& Hasday, 2013).

In addition to enhancing cellular responses, heat-stress increases cardiac output, plasma volume and peripheral blood flow, and induces detoxification through the liver and kidneys, as well as through the skin via sweating (Crinnion, 2011) through which some toxic elements are preferentially excreted (Genuis et al., 2011). Heat-stress also induces a hormetic stress response that builds 
physiological resilience and confers tolerance to subsequent stress in a similar way to exercise (Gálvez et al., 2018). The effects of heat stress may be further enhanced when it is followed by intermittent cold exposure, which shunts blood to internal organs and induces a diuresis (Epstein, 1978), and further aids in detoxification (Cochrane, 2004). Heat-stress also enhances the immunostimulatory effects of cold exposure on the innate immune system, which include leukocytosis, granulocytosis, an increase in NK cell count and activity, and an elevation in circulating levels of IL-6 (Brenner et al., 1999).

Heat-stress may offer a further advantage against respiratory viral infections by altering blood $\mathrm{pH}$. Hyperthermia induces hyperventilation and subsequent respiratory alkalosis (Tsuji et al., 2016), that creates alkaline conditions that may be more favourable to host defenses. The ability of a transient alkaline environment to inhibit viral replication and reduce infectivity has been demonstrated with human coronavirus 229E, which has maximal infectivity in acid conditions (Lamarre \& Talbot, 1989), and with coronavirus MHV-A59, which undergoes conformational changes in the spike glycoprotein at a $\mathrm{pH}$ of 8 at $37^{\circ} \mathrm{C}$ degrees, which leads to rapid and irreversible inactivation and loss of infectivity (Sturman et al., 1990).

In addition to offering physiological advantages in the battle against viral infection such as COVID-19, heat also confers many psychological advantages. Sauna bathing and other forms of heat therapy require time and effort to be devoted towards active relaxation that can help divert attention from anxiety-producing news and/or relieve boredom associated with social confinement. Sauna bathing also enhances sleep (Hussain et al., 2019), which further supports immune function (Irwin \& Opp, 2017). Engaging in an activity with an intended positive outcome can also impart feelings of control that may otherwise be lacking, and doing something that feels good and having positive expectations elicits the power of positive thought and the placebo effect or 'remembered wellness' (Benson \& Friedman, 1996). Furthermore, the exploration of heat-tolerance induces a 'forced-mindfulness' and a focus on the breath, which has additional physical and psychological benefits (Black \& Slavich, 2016). In a time of social distancing, saunas can also provide a way for close family members to come together in ways that have supported family cohesion for generations in Finland and other Nordic countries (Mather \& Kaups, 1963).

\section{Heat as medicine}

The use of heat for cleansing and healing forms a conscious extension of mammals' use of heat that has been practiced throughout human history. Hot springs, saunas, hammams, steam rooms, sweat lodges, steam inhalations, baths, hot mud and poultices have been used traditionally in cold, dry climates to prevent and treat respiratory infections and to enhance overall health and wellbeing. While heat-based therapies are not widely used in mainstream medicine, other than the local application of hot packs for symptomatic relief, heat-based treatments are standard offerings in wellness establishments, such as hot springs, bathing facilities, gymnasiums, fitness centers, hotels and resorts, where they are used both therapy and recreation (Clark-Kennedy \& Cohen, 2017).
There are multiple lines of evidence to support the use of heat and humidity for the prevention and treatment of viral respiratory infections. Historical and emerging evidence suggests regular sauna bathing enhances cardiovascular, respiratory and immune function as well as improving mood and quality of life (Hussain \& Cohen, 2018). Epidemiological evidence further suggests that frequent sauna bathing is associated with a reduced risk of pneumonia and viral infection (Kunutsor et al., 2017), and randomised controlled trial evidence suggests that regular saunas can halve the incidence of respiratory viral infections (Ernst et al., 1990). Randomised controlled trials further suggest hot air can treat respiratory infection with humidified air at temperatures above $43^{\circ} \mathrm{C}$ for 20 to 30 minutes being found to reduce viral shedding, giving immediate relief of symptoms and improving the course of the common cold (Tyrrell, 1988; Tyrrell et al., 1989).

\section{Clinical applications and implications}

There are a range of heat-based interventions that can be used alongside social distancing, hand washing and other personal hygiene measures to aid in overcoming COVID-19. For example, warming and humidifying indoor environments can prevent drying of the nasal mucosa, increase muco-ciliary clearance and nasal patency, and provide symptomatic relief (Ophir \& Elad, 1987). The direct application of heat to the upper airways at the first signs of infection may further serve to inhibit or deactivate virions in the place where they first lodge. This has been demonstrated in vitro with temperatures of $45^{\circ} \mathrm{C}$ for 20 minutes activating immune cells and releasing HSPs while suppressing rhinovirus multiplication by more than 90\% (Conti et al., 1999). The inhalation of steam with added essential oils with anti-viral, decongestant, anxiolytic and other properties, may further assist in facilitating muco-ciliary clearance and reducing viral load as well as providing physical and psychological relief (Ali et al., 2015; Lee et al., 2017).

Inducing mild heat-stress through the use of hot springs (balneotherapy), hot baths, saunas, steam-rooms and application of hot mud (pelotherapy), can be used to mimic fever and activate immune defenses. Enhanced immunity has been demonstrated with hyperthermia induced by traditional Finnish saunas (Pilch et al., 2013), far-infrared saunas (Sobjima, 2018), heated nano-mist (Tomiyama et al., 2015), hot baths (Downing et al., 1988; Kappel et al., 1991; Tsuchiya et al., 2003; Zellner et al., 2002) and geothermal mineral water (Uzunoglu et al., 2017). The beneficial effects of heat-stress may be further potentiated by the traditional practice of alternating heat with exposure to cold, which has been shown to increase NK cell count and activity and raise circulating levels of IL-6 and norepinephrine (Brenner et al., 1999). This may translate into greater resistance to viral infections as evidenced by a randomised controlled trial that found regular hot and cold showers reduced work absenteeism during an influenza outbreak (Buijze et al., 2016).

In recent years far-infrared (FIR) saunas have been used as an alternative to the traditional Finnish saunas. These saunas use infrared emitters without water or humidity and generally run at lower temperatures than Finnish saunas. While the 
use of FIR saunas to treat viral infection has not been studied, FIR radiation is reported to deactivate single-strand RNA viruses (Huang \& Li, 2020) and FIR saunas have been shown to raise body temperature and induce hormetic stress responses, which support host defenses (Shemilt et al., 2019).

There are currently no clinical protocols for using heat in the treatment of COVID-19, yet heat has a long history of traditional use, and traditional practices such as alternating hot and cold immersions, post-heat relaxation and use of essential oils can inform their development. Heatbased clinical protocols must consider temperature, timing and individual tolerance, along with humidity, as water is 25 times more conductive than air, making steam rooms tolerable at temperatures around $50^{\circ} \mathrm{C}$ while dry saunas can be tolerated at temperatures above $100^{\circ} \mathrm{C}$. Clinical protocols are needed to design future studies and inform clinical practice and while sauna bathing is generally well tolerated, protocols must consider contra-indications such as unstable angina, severe infection, high fever, or concomitant alcohol consumption (Hannuksela \& Ellahham, 2001) and the risk of adverse events, such as fainting, dizziness and burns, along with the risk of cross-infection.

While the clinical application of heat has promise in the prevention and treatment of COVID-19, there are significant challenges in implementing heat-based therapies. The current pandemic has seen the fear of infection lead to the widespread closure of public facilities that offer saunas and heat treatments, such as bathing facilities, commercial hot springs, spas, gymnasiums, hotels and fitness centers, and while some countries such as Finland have a large number of private saunas, in most other locations private sauna ownership is limited to people with high socio-economic status. Thus, if sauna bathing is to be widely implemented, public bathing and sauna facilities will need to adopt infection control measures similar to those for dealing with COVID-19 in hospitals and medical facilities (Liang, 2020).

Heat is one of oldest forms of microbial control and still remains one of the most common methods for controlling and eradicating pathogens. The temperatures achieved within a sauna are well within the range required for pathogen control and often exceed temperatures of $60^{\circ} \mathrm{C}$ for $30 \mathrm{~min}, 65^{\circ} \mathrm{C}$ for $15 \mathrm{~min}$ or $80^{\circ} \mathrm{C}$ for $1 \mathrm{~min}$, which have been shown to reduce coronavirus infectivity by at least $4 \log 10$ (Kampf et al., 2020).
While the temperatures, humidity and times required to specifically deactivate SAR-CoV-2 in vivo are yet to be determined, the temperature within a sauna makes risk of cross infection in public facilities more likely to arise in changing rooms and ancillary spaces rather than within saunas themselves. Strategies for limiting cross infection in bathing facilities therefore need to include disinfection of public areas and managing social distancing and other behavior of staff and bathers.

Strategies for limiting cross infection, including procedures for maintaining social distancing by limiting group size, have been recently developed for re-opening some of the 3000 hot springs that were recently closed in China (Wang, 2020). There are also moves to reopen facilities as quarantine zones where people can undergo heat treatments during isolation or as places of respite for overworked medical staff. It may also be possible for saunas and steam rooms to be included within hospitals and rehabilitation facilities for use by both patients and staff. Furthermore, simple home-based protocols can provide guidance on using heat for people who are currently self-isolated in their homes or in quarantine. Such protocols could be evaluated using crowd-sourced, citizen-science platforms, which may help to develop, test and optimize treatment strategies for current and future pandemics.

\section{Conclusion}

Heat is a cheap, convenient and widely accessible therapeutic modality with a long history of traditional use, yet it remains to be seen whether heat can be effective in the treatment or prevention of COVID-19. The relatively low cost and wide availability of heat-based treatments, along with multiple mechanisms of action that include both physical and psychological dimensions, makes heat an attractive option for combating viral infections. The integration of these ancient forms of treatment with modern technology may lead to a greater integration of natural therapies in mainstream healthcare, with the potential to support the wellbeing of both patients and medical staff. This may also lead to a greater convergence between the healthcare and wellness industries, and the development of systems and activities that build the wellbeing and resilience of the wider community, thereby reducing the impact of future pandemics.

\section{Data availability}

No data is associated with this work.
Ali B, Al-Wabel NA, Shams S, et al.: Essential oils used in aromatherapy: A systemic review. Asian Pac J Trop Biomed. 2015; 5(8): 601-611. Publisher Full Text

Benson H, Friedman R: Harnessing the power of the placebo effect and renaming it "remembered wellness". Annu Rev Med. 1996; 47: 193-199. PubMed Abstract | Publisher Full Text
Black DS, Slavich GM: Mindfulness meditation and the immune system: a systematic review of randomized controlled trials. Ann N Y Acad Sci. 2016; 1373(1): 13-24.

PubMed Abstract | Publisher Full Text | Free Full Text

Brenner IK, Castellani JW, Gabaree C, et al.: Immune changes in humans during cold exposure: effects of prior heating and exercise. J Appl Physiol (1985). 
1999; 87(2): 699-710.

PubMed Abstract | Publisher Full Text

Buijze GA, Sierevelt IN, van der Heijden BC, et al.: The Effect of Cold Showering on Health and Work: A Randomized Controlled Trial. PLOS One. 2016; 11(9): e0161749.

PubMed Abstract | Publisher Full Text | Free Full Text

Chan KH, Peiris JS, Lam SY, et al:: The Effects of Temperature and Relative Humidity on the Viability of the SARS Coronavirus. Adv Virol. 2011; 2011: 734690 .

PubMed Abstract | Publisher Full Text | Free Full Text

Clark-Kennedy J, Cohen M: Indulgence or therapy? Exploring the

characteristics, motivations and experiences of hot springs bathers

in Victoria, Australia. Asia Pacific Journal of Tourism Research. 2017; 22(5):

501-511.

Publisher Full Text

Cochrane DJ: Alternating hot and cold water immersion for athlete recovery: a review. Physical Therapy in Sport. 2004; 5(1): 26-32.

Publisher Full Text

Conti C, De Marco A, Mastromarino P, et al.: Antiviral effect of hyperthermic treatment in rhinovirus infection. Antimicrob Agents Chemother. 1999; 43(4): 822-829.

PubMed Abstract | Publisher Full Text | Free Full Text

Crinnion WJ: Sauna as a valuable clinical tool for cardiovascular, autoimmune, toxicant- induced and other chronic health problems. Altern Med Rev. 2011; 16(3): 215-225.

PubMed Abstract

Darnell ME, Subbarao K, Feinstone SM, et al: Inactivation of the coronavirus that induces severe acute respiratory syndrome, SARS-CoV. $J$ Virol Methods. 2004; 121(1): 85-91.

PubMed Abstract | Publisher Full Text | Free Full Text

Downing JF, Martinez-Valdez H, Elizondo RS, et al:: Hyperthermia in humans enhances interferon-gamma synthesis and alters the peripheral lymphocyte population. J Interferon Res. 1988; 8(2): 143-150.

PubMed Abstract | Publisher Full Text

Duan SM, Zhao XS, Wen RF, et al:: Stability of SARS coronavirus in human specimens and environment and its sensitivity to heating and UV irradiation. Biomed Environ Sci. 2003; 16(3): 246-255.

PublMed Abstract

Epstein M: Renal effects of head-out water immersion in man: implications for an understanding of volume homeostasis. Physiol Rev. 1978; 58(3): 529-581.

PubMed Abstract | Publisher Full Text

Ernst $\mathrm{E}$, Pecho $\mathrm{E}$, Wirz $\mathrm{P}$, et al:: Regular sauna bathing and the incidence of common colds. Ann Med. 1990; 22(4): 225-227.

PubMed Abstract | Publisher Full Text

Evans SS, Repasky EA, Fisher DT: Fever and the thermal regulation of immunity: the immune system feels the heat. Nat Rev Immunol. 2015; 15(6): 335-349. PubMed Abstract | Publisher Full Text | Free Full Text

Fahy JV, Dickey BF: Airway mucus function and dysfunction. N Engl J Med. 2010; 363(23): 2233-2247.

PubMed Abstract | Publisher Full Text | Free Full Text

Gálvez I, Torres-Piles S, Ortega-Rincón E: Balneotherapy, Immune System, and Stress Response: A Hormetic Strategy? Int J Mol Sci. 2018; 19(6): pii: E1687. PubMed Abstract | Publisher Full Text | Free Full Text

Genuis SJ, Birkholz D, Rodushkin I, et al.: Blood, urine, and sweat (BUS) study: monitoring and elimination of bioaccumulated toxic elements. Arch Environ

Contam Toxicol. 2011; 61(2): 344-357.

PubMed Abstract | Publisher Full Text

Gujrathi AB, Ambulgekar V, Handal A: Effect of Steam Inhalation on Nasa

Mucociliary Clearance in Normal Individuals and Nasal Disease State. Journa

of Contemporary Medical Research. 2016; 3(5): 1262-1264

Reference Source

Hannuksela ML, Ellahham S: Benefits and risks of sauna bathing. Am J Med. 2001; 110(2): 118-126.

PubMed Abstract | Publisher Full Text

Hu L, Trefethen JM, Zeng Y, et al:: Biophysical characterization and

conformational stability of Ebola and Marburg virus-like particles. J Pharm Sci. 2011: 100(12): 5156-5173.

PubMed Abstract | Publisher Full Text

Huang WH, Li EJ: Instability of Nucleic Acids in Airborne Microorganisms under Far Infrared Radiation. Preprints.org. 2020.

Publisher Full Text

Hussain J, Cohen M: Clinical Effects of Regular Dry Sauna Bathing: A Systematic Review. Evid Based Complement Alternat Med. 2018; 2018: 1857413. PubMed Abstract | Publisher Full Text | Free Full Text

Hussain JN, Greaves RF, Cohen MM: A hot topic for health: Results of the

Global Sauna Survey. Complement Ther Med. 2019; 44: 223-234.

PubMed Abstract | Publisher Full Text

Iguchi M, Littmann AE, Chang $\mathrm{SH}$, et al:: Heat stress and cardiovascular, hormonal, and heat shock proteins in humans. J Athl Train. 2012; 47(2): 184-190.

PubMed Abstract | Publisher Full Text | Free Full Tex

Irwin MR, Opp MR: Sleep Health: Reciprocal Regulation of Sleep and Innate
Immunity. Neuropsychopharmacology. 2017; 42(1): 129-155.

PubMed Abstract | Publisher Full Text | Free Full Text

Kampf G, Voss A, Scheithauer S: Inactivation of coronaviruses by heat. J Hosp Infect. 2020; pii: S0195-6701(20)30124-9.

PubMed Abstract | Publisher Full Text

Kappel M, Stadeager C, Tvede N, et al.: Effects of in vivo hyperthermia on natural killer cell activity, in vitro proliferative responses and blood mononuclear cell subpopulations. Clin Exp Immunol. 1991; 84(1): 175-180. PubMed Abstract | Publisher Full Text | Free Full Text

Kudo E, Song E, Yockey LJ, et al.: Low ambient humidity impairs barrie function and innate resistance against influenza infection. Proc Natl Acad SCi U S A. 2019; 116(22): 10905-10910.

PubMed Abstract | Publisher Full Text | Free Full Text

Kunutsor SK, Laukkanen T, Laukkanen JA: Frequent sauna bathing may reduce the risk of pneumonia in middle-aged Caucasian men: The KIHD prospective cohort study. Respir Med. 2017; 132: 161-163.

PubMed Abstract | Publisher Full Text

Lamarre A, Talbot PJ: Effect of pH and temperature on the infectivity of human coronavirus 229E. Can J Microbiol. 1989; 35(10): 972-974.

PubMed Abstract | Publisher Full Text

Lee Mk, Lim S, Song JA, et al:: The effects of aromatherapy essential

oil inhalation on stress, sleep quality and immunity in healthy adults:

Randomized controlled trial. Eur J Integr Med. 2017; 12: 79-86.

Publisher Full Text

Lelie PN, Reesink HW, Lucas CJ: Inactivation of 12 viruses by heating steps applied during manufacture of a hepatitis B vaccine. J Med Virol. 1987; 23(3): 297-301.

PubMed Abstract | Publisher Full Text

Liang TE: Handbook of COVID-19 Preventionand Treatment China. The First Affiliated Hospital, Zhejiang University School of Medicine. 2020.

Reference Source

Mace TA, Zhong L, Kilpatrick C, et al.: Differentiation of CD8+ T cells into effector cells is enhanced by physiological range hyperthermia. $J$ Leukoc Biol. 2011; 90(5): 951-962.

PubMed Abstract | Publisher Full Text | Free Full Text

Mäkinen TM, Juvonen R, Jokelainen J, et al:: Cold temperature and low humidity are associated with increased occurrence of respiratory tract infections.

Respir Med. 2009; 103(3): 456-462.

PubMed Abstract | Publisher Full Text

Mather C, Kaups M: The Finnish Sauna: A cultural index to settlement. Annals of the Association of American Geographers. 1963; 53(4): 494-504.

Reference Source

Ophir D, Elad Y: Effects of steam inhalation on nasal patency and nasal symptoms in patients with the common cold. Am J Otolaryngol. 1987; 8(3): 149-153.

PubMed Abstract | Publisher Full Text

Pilch W, Pokora I, Szyguła Z, et al.: Effect of a single finnish sauna session on white blood cell profile and cortisol levels in athletes and non-athletes. J Hum Kinet. 2013; 39: 127-135.

PubMed Abstract | Publisher Full Text | Free Full Text

Sajadi MM, Habibzadeh P, Vintzeleos A, et al.: Temperature and Latitude Analysis to Predict Potential Spread and Seasonality for COVID-19. 2020. Reference Source

Schieber AMP, Ayres JS: Thermoregulation as a disease tolerance defense strategy. Pathog Dis. 2016; 74(9); pii: ftw106.

PubMed Abstract | Publisher Full Text | Free Full Tex

Shemilt R, Bagabir $\mathrm{H}$, Lang $\mathrm{C}$, et al: Potential mechanisms for the effects of farinfrared on the cardiovascular system - a review. Vasa. 2019; 48(4): 303-312. PubMed Abstract | Publisher Full Text

Singh IS, Hasday JD: Fever, hyperthermia and the heat shock response. Int $J$ Hyperthermia. 2013; 29(5): 423-435.

PubMed Abstract | Publisher Full Text

Sobajima M, Nozawa T, Ihori $\mathrm{H}$, et al: Repeated Low-Temperature Sauna Therapy Improves Cardiac and Exercise Capacity as well as Immune Competence in Patients with Heart Failure. Circulation. 2018; 126(suppl_21): A10868.

Reference Source

Soni B, Nayak AK: Effect of inspiration cycle and ventilation rate on heat exchange in human respiratory airways. $J$ Therm Biol. 2019; 84: 357-367. PubMed Abstract | Publisher Full Text

Sturman LS, Ricard CS, Holmes KV: Conformational change of the coronavirus peplomer glycoprotein at $\mathrm{pH} \mathbf{8 . 0}$ and $\mathbf{3 7}$ degrees $\mathrm{C}$ correlates with virus aggregation and virus-induced cell fusion. $J$ Virol. 1990; 64(6): 3042-50. PubMed Abstract | Publisher Full Text | Free Full Text

Tomiyama C, Watanabe M, Honma T, et al:: The effect of repetitive mild hyperthermia on body temperature, the autonomic nervous system, and innate and adaptive immunity. Biomed Res. 2015; 36(2): 135-142.

PubMed Abstract | Publisher Full Text

Tsan MF, Gao B: Heat shock proteins and immune system. J Leukoc Biol. 2009; 85(6): 905-910.

PubMed Abstract | Publisher Full Text

Tsuchiya Y, Shimizu T, Tazawa T, et al.: Effects of hot deep seawater bathing 
on the immune cell distribution in peripheral blood from healthy young men. Environ Health Prev Med. 2003; 8(5): 161-165.

PubMed Abstract | Publisher Full Text | Free Full Text

Tsuji B, Hayashi K, Kondo N, et al:: Characteristics of hyperthermia-induced hyperventilation in humans. Temperature (Austin). 2016; 3(1): 146-160. PubMed Abstract | Publisher Full Text | Free Full Text

Tyrrell D, Barrow I, Arthur J: Local hyperthermia benefits natural and experimental common colds. BMJ. 1989; 298(6683): 1280-1283. PubMed Abstract | Publisher Full Text | Free Full Text

Tyrrell DA: Hot news on the common cold. Annu Rev Microbiol. 1988; 42: 35-47. PubMed Abstract | Publisher Full Text

Uzunoglu E, Yentur S, Kayar AH, et al.: Effect of mild heat stress on heat shock protein 70 in a balneotherapy model. Eur J Integr Med. 2017; 9(C): 86-90.

Publisher Full Text
Wang J: Crisis and Opportunities for the Chinese Hot Springs Industry in Year 2020. China, Asia-Pacific Institute for Hydrotherapy and Climatotherapy Tourism. 2020.

Reference Source

Wang J, Tang K, Feng K, et al:: High Temperature and High Humidity Reduce the Transmission of COVID-19. 2020.

Reference Source

WHO Report: First data on stability and resistance of SARS coronavirus compiled by members of WHO laboratory network, WHO Multi-center Collaborative Network on SARS Diagnosis. 2003.

Reference Source

Zellner M, Hergovics N, Roth E, et al:: Human monocyte stimulation by experimental whole body hyperthermia. Wien Klin Wochenschr. 2002; 114(3): 102-107.

PubMed Abstract 


\section{Open Peer Review}

\section{Current Peer Review Status:}

\section{Version 1}

Reviewer Report 07 July 2020

https://doi.org/10.5256/f1000research.25720.r62786

(c) 2020 Laukkanen J. This is an open access peer review report distributed under the terms of the Creative Commons Attribution License, which permits unrestricted use, distribution, and reproduction in any medium, provided the original work is properly cited.

\section{? Jari Laukkanen}

Institute of Clinical Medicine, Department of Medicine, University of Eastern Finland, Kuopio, Finland

Heat is a cheap, convenient and widely accessible therapeutic modality. Sauna bathing is a form of heat therapy. However, there are no very accurate details of temperature, weekly frequency, and duration which would be needed to achieve those beneficial effects. An only traditional Finnish sauna is based on high temperatures.

You should discuss more with the lights of many published original studies on sauna and its protective health effects. The literature review of this narrative has missed many recent papers on this topic. Please consider adding the recently published key references on sauna and health outcomes so that this article would be more up-to-date. ${ }^{1,2}$, [ref-3,4,5,6,7

What is the role of improved hygiene control due to regular sauna bathing?

Warm and cold has any effect on the results?

You could add studies that may indicate that sauna is related to inflammatory markers or cytokines.

It is written that emerging evidence suggests regular sauna bathing enhances cardiovascular function. No relevant references were available in the manuscript.

\section{References}

1. Laukkanen JA, Laukkanen T, Kunutsor SK: Cardiovascular and Other Health Benefits of Sauna Bathing: A Review of the Evidence.Mayo Clin Proc. 93 (8): 1111-1121 PubMed Abstract | Publisher Full Text

2. Kunutsor SK, Laukkanen T, Laukkanen JA: Longitudinal associations of sauna bathing with inflammation and oxidative stress: the KIHD prospective cohort study.Ann Med. 50 (5): 437-442 PubMed Abstract | Publisher Full Text 
3. Heinonen I, Laukkanen J: Effects of heat and cold on health, with special reference to Finnish sauna bathing. American Journal of Physiology-Regulatory, Integrative and Comparative Physiology. 2018; 314 (5): R629-R638 Publisher Full Text

4. Laukkanen J, Laukkanen T: Sauna bathing and systemic inflammation. European Journal of Epidemiology. 2018; 33 (3): 351-353 Publisher Full Text

5. Kunutsor S, Laukkanen T, Laukkanen J: Sauna bathing reduces the risk of respiratory diseases: a long-term prospective cohort study. European Journal of Epidemiology. 2017; 32 (12): 1107-1111 Publisher Full Text

6. Laukkanen T, Khan H, Zaccardi F, Laukkanen JA: Association between sauna bathing and fatal cardiovascular and all-cause mortality events.JAMA Intern Med. 2015; 175 (4): 542-8 PubMed Abstract | Publisher Full Text

7. Laukkanen JA, Kunutsor SK: Is sauna bathing protective of sudden cardiac death? A review of the evidence.Prog Cardiovasc Dis. 62 (3): 288-293 PubMed Abstract | Publisher Full Text

Is the topic of the opinion article discussed accurately in the context of the current literature?

Yes

Are all factual statements correct and adequately supported by citations? Yes

Are arguments sufficiently supported by evidence from the published literature? Yes

Are the conclusions drawn balanced and justified on the basis of the presented arguments? Yes

Competing Interests: No competing interests were disclosed.

Reviewer Expertise: Cardiovascular diseases, sauna and exercise

I confirm that I have read this submission and believe that I have an appropriate level of expertise to confirm that it is of an acceptable scientific standard, however I have significant reservations, as outlined above.

Author Response 12 Jul 2020

Marc Cohen, Extreme Wellness Institute, Melbourne, Australia

Thank you for your suggestions. I have expanded the content on cardio-respiratory function and added all the suggested references on sauna bathing and health outcomes.

Competing Interests: No competing interests were disclosed. 
(C) 2020 Repasky E. This is an open access peer review report distributed under the terms of the Creative Commons Attribution License, which permits unrestricted use, distribution, and reproduction in any medium, provided the original work is properly cited.

\section{Elizabeth A. Repasky}

Department of Immunology, Roswell Park Comprehensive Cancer Center, Buffalo, NY, USA

This is a timely, interesting, and generally well-written article summarizing many of the positive benefits of thermal therapies, provided in the context of potential therapies for patients with COVID-19. In general, the authors cover a wide range of literature related to applications (local/regional, whole body, topical) of elevated temperature. My comments related only to organization and some references and distinguishing better the difference between fever and hyperthermia. Heat treatments are likely to be hyperthermia treatments. While fever contains a thermal element, fever and hyperthermia represent very different physiological circumstances.

For example, statements such as that in Paragraph 2, right column, page3 "Fever has multiple actions with dealing with infections that include direct inhibition of pathogens, stimulation of both the innate and adaptive arms of the immune system and activation....". While the authors provide a review article as a reference here, most of this literature deals with hyperthermia and not actual infectious fever and this difference needs to be highlighted better. One would not be treated with fever. Moreover, there are other fundamental differences. Febrile individuals are usually quite cold and surface vessels constricted to conserve heat and help raise body temperature. Hyperthermia causes sweating and surface blood vessel dilation because the set point is not elevated. Moreover, there is a massive literature on heat stress/stroke (from hyperthermia, not fever) that can kill people because of excessive adhesion of platelets and white blood cells in capillaries. While the authors do rightly mention some safety concerns, it is perhaps a bit insufficient with regard to the impact of both hyperthermia (and fever). At the same time, the scope of the beneficial effects of mild elevation of body temperature and local temperature (in particular with respect to viral infections) is quite important to remember and hopefully expand upon in future clinical applications.

Some topics should be highlighted more. For example, there is a substantial literature using electromagnetic heating and infrared heating for cancer therapy and so there is already safe equipment available for both local/regional as well as surface heating. Reviews on this topic have been available for some time. This technology could already be available for COVID-19 patients.

I found some of the referencing related to the direct impact of heat on viral replication (either in vivo (e.g., nasal cavities or in vitro) to be scattered a bit throughout the review. Some better reorganization of these various sections would help the reader to assess this very important point.

Is the topic of the opinion article discussed accurately in the context of the current literature?

Partly

Are all factual statements correct and adequately supported by citations? 
Yes

Are arguments sufficiently supported by evidence from the published literature?

Yes

Are the conclusions drawn balanced and justified on the basis of the presented arguments? Yes

Competing Interests: No competing interests were disclosed.

Reviewer Expertise: Immunology; Thermal stress; hyperthermia, anti-tumor immunity; Stress

I confirm that I have read this submission and believe that I have an appropriate level of expertise to confirm that it is of an acceptable scientific standard.

Author Response 12 Jul 2020

Marc Cohen, Extreme Wellness Institute, Melbourne, Australia

I agree that this is a timely and interesting topic that covers a wide range of literature and am grateful for your comments, which have led to improvements in the paper's content and flow. I have now modified the wording to better reflect the difference between fever and externally applied heat stress and have referenced a review of the different forms of heat treatment that are currently being used or are under investigation for cancer therapy and suggest they may be useful for treating COVID-19. I have also added more detail on the adverse effects of heat and have reorganised some sections to improve the flow of information and make the paper more cohesive.

Competing Interests: All competing interests have been declared in the authorship statement.

\section{Comments on this article}

\section{Version 1}

\section{Reader Comment 19 Jul 2020}

Erik Kulstad, UT Southwestern Medical Center, Dallas, USA

Good overview of the topic of temperature and its influence on infectious disease (a topic of increasing interest, particularly in the current global pandemic). Work by Drs. Anne Drewry and Richard Hotchkiss out of Washington University in St. Louis would be worth including here, as they have led the way in this area, including having recently completed the first randomized-controlled clinical trial on this effect: (ClinicalTrials.gov listing: Pilot Trial of External Warming in Septic Patients). We have also posted a planned clinical trial protocol, and published initial mathematical 
modeling, in this area, and expect to have clinical data in the coming months.

- ClinicalTrials.gov listing for upcoming Wash U study: Core Warming of COVID-19 Patients

- Protocol: Core warming of coronavirus disease 2019 (COVID-19) patients undergoing mechanical ventilation: protocol for a randomized controlled pilot study

- Recent publication on warming in COVID-19: The Use of Core Warming as a Treatment for Coronavirus Disease 2019 (COVID-19): an Initial Mathematical Model

- Recent letter on warming in Critical Care: Response to "COVID-19: room for treating T cell exhaustion?"

Competing Interests: Equity ownership of a company, Attune Medical, with technology in the patient temperature management space.

Reader Comment 24 Jun 2020

Shahar Seifer, Weizmann Institute of Science, Chemical and Biological Physics, Israel

The arguments in this article are solid, especially on account of the article of Soni \& Nayak and the data on SARS-Cov-2 virus. The world is missing the simple fact that this fragile virus can be defeated by a simple mean of thermal treatment on the initial stage of the disease, before the patient is hospitalized. The author did a great literature survey, yet there are more relevant articles that describe the mechanism of action and experiments with hot air breathers. Certainly anyone who experienced spa treatment can appreciate its powerful effect on the body and mind. If logistically such treatment is unattainable for corona carriers we might encourage household medical devices for such purpose. Caution is required, since excessive heat can also increase inflammation several days after the treatment, which may increase the cytokine storm.

Hence exposure should be gradual, and the mechanism of thermotolerance may be an important factor in such treatment.

Competing Interests: Competing interests: none 
The benefits of publishing with F1000Research:

- Your article is published within days, with no editorial bias

- You can publish traditional articles, null/negative results, case reports, data notes and more

- The peer review process is transparent and collaborative

- Your article is indexed in PubMed after passing peer review

- Dedicated customer support at every stage

For pre-submission enquiries, contact research@f1000.com 